\title{
Structure determination of riboflavin by synchrotron high-resolution powder X-ray diffraction
}

\section{Mathieu Guerain, Frédéric Affouard, Charline Henaff, Catherine Dejoie, Florence Danède, Juergen Siepman, Florence Siepman and Jean-François Willart}

Acta Cryst. (2021). C77, 800-806

\section{IUCr Journals CRYSTALLOGRAPHY JOURNALS ONLINE}

Author(s) of this article may load this reprint on their own web site or institutional repository provided that this cover page is retained. Republication of this article or its storage in electronic databases other than as specified above is not permitted without prior permission in writing from the IUCr.

For further information see https://journals.iucr.org/services/authorrights.html 


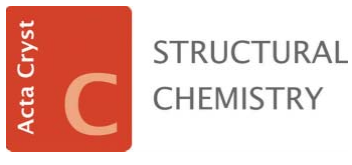

ISSN 2053-2296
Received 29 July 2021

Accepted 16 November 2021

Edited by I. Oswald, University of Strathclyde, United Kingdom

Keywords: powder diffraction; crystal structure; riboflavin; Monte Carlo simulated annealing; computational energy minimization; API; synchrotron.

CCDC reference: 2122541

Supporting information: this article has supporting information at journals.iucr.org/C

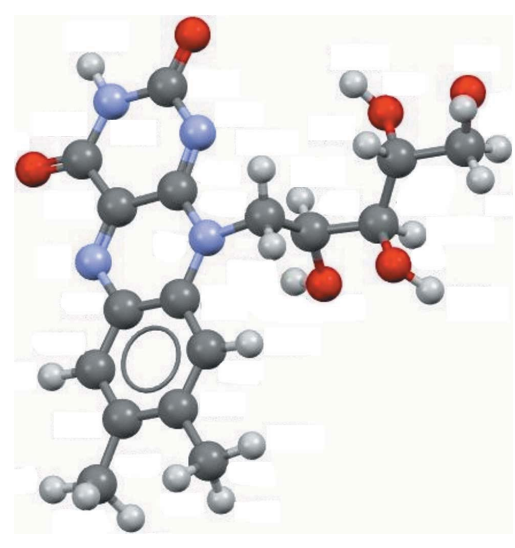

\section{Structure determination of riboflavin by synchro- tron high-resolution powder X-ray diffraction}

\author{
Mathieu Guerain, ${ }^{\mathrm{a} *}$ Frédéric Affouard, ${ }^{\mathrm{a}}$ Charline Henaff, ${ }^{\mathrm{a}}$ Catherine Dejoie, ${ }^{\mathrm{b}}$ \\ Florence Danède, ${ }^{a}$ Juergen Siepman, ${ }^{c}$ Florence Siepmanc and Jean-François \\ Willart $^{\mathrm{a}}$
}

\begin{abstract}
a Université de Lille, CNRS, INRAE, Centrale Lille, UMR 8207 - UMET - Unité Matériaux et Transformations, F-59000 Lille, France, ${ }^{\mathbf{b}}$ European Synchrotron Radiation Facility, 71 avenue des Martyrs, 38000 Grenoble, France, and ${ }^{\mathbf{c}}$ Université de Lille, Inserm, CHU Lille, U1008, F-59000 Lille, France. *Correspondence e-mail: mathieu.guerain@univ-lille.fr
\end{abstract}

The crystal structure of the stable form of vitamin $\mathrm{B} 2$ or riboflavin $\left(\mathrm{C}_{17} \mathrm{H}_{20} \mathrm{~N}_{4} \mathrm{O}_{6}\right)$ was solved using high-resolution powder X-ray diffraction (PXRD). The highresolution PXRD pattern of riboflavin was recorded at room temperature at the European Synchrotron Radiation Facility (Grenoble, France). The starting structural model was generated using a Monte Carlo simulated annealing method. The final structure was obtained through Rietveld refinement. The positions of the $\mathrm{H}$ atoms belonging to hydroxy groups were estimated from computational energy minimizations. The symmetry is orthorhombic with the space group $P 2_{1} 2_{1} 2_{1}$ and the following lattice parameters: $a=20.01308, b=$ 15.07337 and $c=5.31565 \AA$.

\section{Introduction}

Many drugs are characterized by poor solubility in water and body fluids which can strongly limit their therapeutic performance. Increasing the solubility of poorly soluble drugs is thus a frequently encountered major challenge in the development of pharmaceuticals. This goal can be achieved, for instance, by formulating the drug in a high energetic physical state, such as a metastable polymorphic form or an amorphous state (Saifee et al., 2010; Mahieu et al., 2013). However, such a manipulation of the physical state should be based on a good knowledge of both the potential polymorphism and the phase diagram of the drug. Milling the crystal can also strongly improve both the solubility and the dissolution rate of a drug. This is due to the reduction of the size of the crystallite (Zimper et al., 2010a; Chu et al., 2012) and, in some cases, to the formation of some structural disorder that can lead to partial or total amorphization of the sample (Willart \& Descamps, 2008; Bordet et al., 2016; Zimper et al., 2010b). For these reasons, it is important to control both the structure and the microstructure of crystalline powders during milling processes (Blagden et al., 2007). This can be achieved by powder X-ray diffraction, provided that the crystalline structure of the material is known (Willart et al., 2005; Martinetto et al., 2017).

Riboflavin \{systematic name: 7,8-dimethyl-10-[(2R,3R,4S)2,3,4,5-tetrahydroxypentyl]benzo[ $g]$ pteridine-2,4(3H,10H)-dione, $\mathrm{C}_{17} \mathrm{H}_{20} \mathrm{~N}_{4} \mathrm{O}_{6}$ \} (Fig. 1), commonly known as vitamin $\mathrm{B} 2$, is a photosensitive vitamin widely used in parenteral nutrition (de Farias et al., 2018). This vitamin is characterized by a limited solubility in water (i.e. $100-130 \mathrm{mg} \mathrm{l}^{-1}$ at $25^{\circ} \mathrm{C}$; Furia, 1972). Its formulation in a high-energy state would strongly improve this situation, but, up to now, little is known about the polymorphism of this compound. Besides the stable crystalline 
form, two metastable polymorphs have been mentioned in the literature without any deep physical characterization (Dale, 1952; Means et al., 1943). In particular, their crystalline structures are totally unknown. The stable crystalline form of riboflavin was more deeply characterized by thermogravimetric analysis (TGA), differential scanning calorimetry (DSC) and X-ray diffraction (Ferreira et al., 2019), but its crystalline structure remains currently unknown. This assessment was verified by coupling the search/match functionalities of the Highscore software with the Cambridge Structural Database (CSD; Groom et al., 2016), the Crystallographic Open Database (COD; http://www.crystallography.net/cod/) and the PDF-2 database of the International Center for Diffraction Data (ICDD; https://www.icdd.com/). From this thorough research, only two cocrystals formed with riboflavin were identified, namely, adenine-riboflavin trihydrate (CSD refcode: ADRBFT10; Fujii et al., 1977) and the complex riboflavin-5'-bromo-5'-deoxyadenosine trihydrate (CSD refcode: RIBBAD; Voet \& Rich, 1971).

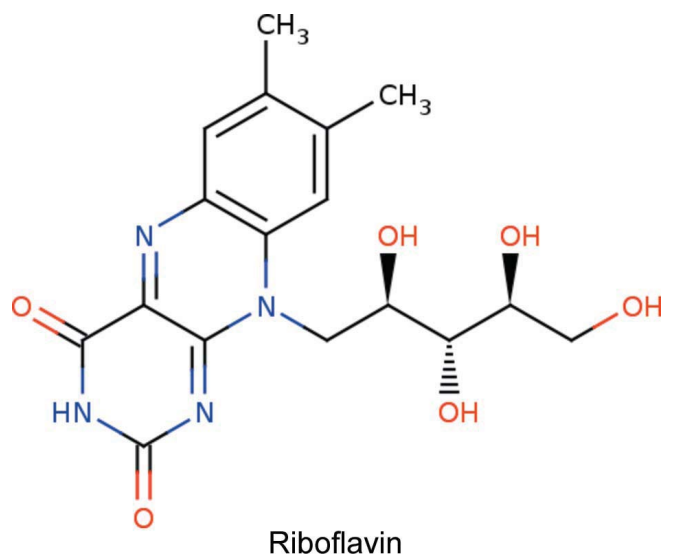

The present article aims to resolve the structure of the stable crystalline form of riboflavin. The structure was solved $a b$ initio from synchrotron high-resolution powder X-ray diffraction using a direct-space approach (simulated annealing), followed by application of the Rietveld method.

Since $\mathrm{H}$ atoms are light, they are notoriously difficult to detect using X-ray diffraction methods. While the position of some $\mathrm{H}$ atoms can be inferred based on simple geometrical arguments, an exact knowledge of the atomic positions of the $\mathrm{H}$ atoms belonging to hydroxy groups $(-\mathrm{OH})$ remains a major challenge. In the present study, the positions of such $\mathrm{H}$ atoms were thus estimated using a three-step numerical approach combining: (i) the generation of structurally reasonable possible hydroxy $\mathrm{H}$-atom positions based on the positions of the acceptor and donor atoms (oxygen and nitrogen) in the structure, (ii) fast energy minimizations of all the generated possible structures using a simple classical force field (Wang et $a l ., 2004)$ in order to rapidly select the energetically more favourable ones with a long-range hydrogen-bonding network and (iii) further energy minimizations using periodic density functional theory (DFT) with fixed-cell dispersion-corrected density functional theory (DFT-D) (Giannozzi et al., 2009, 2017), which are more accurate but more computationally demanding.

\section{Experimental}

\subsection{Riboflavin}

Riboflavin (purity 98\%), with a molecular weight of $376.36 \mathrm{~g} \mathrm{~mol}^{-1}$, was purchased from ACROS Organics (Geel, Belgium) and the material was used without further purification. This active pharmaceutical ingredient (API) is an orange-yellow crystalline powder with a yeast-like odour and a bitter taste (Al-Shammary et al., 1990).

\subsection{Data collection}

High-resolution powder X-ray diffraction data were collected at the high-resolution powder diffraction beamline ID22 of the European Synchrotron Radiation Facility (ESRF, Grenoble, France). The beamline was equipped with a 2D Eiger2 2M-W CdTe detector, preceded by nine Si 111 analyzer crystals (Dejoie et al., 2018) mounted on the $2 \theta$ arm. Data were collected at room temperature at a wavelength of $0.354196 \AA$ ( $35 \mathrm{keV})$. An Si NIST 640c sample was used for calibration. The crystal powder was enclosed in a glass capillary (diameter $1 \mathrm{~mm}$ ) and mounted on the diffractometer. In order to cope with radiation damage, 75 patterns were collected at a speed of $8^{\circ} \min ^{-1}$ over $20^{\circ}(2 \theta)$ along the capillary. The pattern resulting from the average of the 75 patterns was used for structure solution and refinement.

\section{Structure solution and refinement}

For the determination of the lattice parameters, the profiles of 20 reflections with a $2 \theta$ angle lower than $12^{\circ}$ were refined individually with the program $D A S H$ (David et al., 2006) in order to obtain their $2 \theta$ angular positions. The $2 \theta$ values of these reflections were computed with the program DICVOL (Boultif \& Louër, 2004) and these reflections were indexed. This method was repeated over 20 times, each time on different sets of peaks. An orthorhombic cell was systematically found. It provided the higher figure of merit with the following parameters: $a=20.015 \pm 0.001, b=15.074 \pm 0.001$, $c=5.316 \pm 0.001 \AA$ and $V=1604 \pm 0.2 \AA^{3}$. The calculated figures of merit are $M(20)=340$ and $F(20)=2007$ (de Wolff $e t$ al., 1968; Smith \& Snyder, 1979).

For the determination of the space group, the $D A S H$ probabilistic approach (Markvardsen et al., 2008), based on the systematic absences of the Bragg peaks, was used. Eight individual peaks distributed over the whole $2 \theta$ range of the pattern were fitted to determine the peak-shape parameters, then the background, unit-cell and zero-point parameters were refined, and the more probable space group was calculated using Pawley refinement (Pawley, 1981). This method was repeated over ten times, each time on different sets of peaks. This led systematically to the space group $P 2_{1} 2_{1} 2_{1}$, which is the most probable space group for an orthorhombic cell according to the Cambridge Structural Database (CSD), with the cell containing four molecules.

Using the space group $P 2{ }_{1} 2_{1} 2_{1}$ and the unit-cell parameters obtained previously, the X-ray diffraction pattern was refined using Pawley fitting (Pawley, 1981) with the program DASH. 
Table 1

Crystallographic data, profile and structural parameters for riboflavin obtained after Rietveld refinement.

\begin{tabular}{ll}
\hline Crystal data & \\
Chemical formula & $\mathrm{C}_{17} \mathrm{H}_{20} \mathrm{~N}_{4} \mathrm{O}_{6}$ \\
$M_{\mathrm{r}}$ & 376.37 \\
Cell setting, space group & Orthorhombic, $P 2_{1} 2_{1} 2_{1}$ \\
Temperature (K) & 293 \\
$a, b, c(\AA)$ & $20.01308(15), 15.07337(12)$, \\
& $5.31565(4)$ \\
$V\left({ }^{\circ}\right)$ & $1603.54(2)$ \\
$Z$ & 4 \\
$F(000)$ & 792 \\
$\mu\left(\mathrm{mm}^{-1}\right)$ & 0.04 \\
Specimen shape, size (mm) & Cylinder, 1 \\
$2 \theta$ range $\left.{ }^{\circ}\right)$ & $0-12$ \\
& \\
Data collection & ID22 (ESRF) \\
Beamline & 1 mm diameter glass capillary \\
Specimen mounting & Transmission \\
Data collection mode & Continuous scan \\
Scan method & Synchrotron $35 \mathrm{KeV}, \lambda=$ \\
Radiation type & $0.354196 \AA$ \\
Binning size ( $\left.{ }^{\circ} 2 \theta\right)$ & 0.001 \\
& \\
Refinement & $R=0.0837, R_{\text {wp }}=0.1125, R_{\text {exp }}=$ \\
$R$ factors and goodness-of-fit & 0.0355 \\
& \\
\hline
\end{tabular}

The refinement was performed from $2 \theta=1.5-12^{\circ}$. Again, eight individual peaks distributed over the whole $2 \theta$ range of the pattern were fitted to determine the peak-shape parameters. A five-term polynomial representing the background, the reflection intensities, the unit-cell parameters, the zero point and the peak shape were refined. This led to an excellent correlation between the experimental diagram and the Pawley fitting to the profile, with $\chi^{2}=1.92$. This result was used for the structure solution.

In order to determine a structural model, the simulated annealing algorithm of the program $D A S H$ was used. The starting configuration of the riboflavin molecule was borrowed from a computed model deposited in PubChem (PubChem CID = 493570; https://pubchem.ncbi.nlm.nih.gov/). The Mercury software was used to confirm that the computed molecule corresponded well to the 2D model of riboflavin (Macrae et al., 2020). The molecule was introduced randomly in the cell. The restraint options used for the calculations did not modify the bond lengths and angles. The translation and orientation parameters of the molecule in the cell, as well as the torsion angles $(\mathrm{C} 11-\mathrm{C} 12-\mathrm{N} 7-\mathrm{C} 15, \mathrm{O} 1-\mathrm{C} 11-\mathrm{C} 12-\mathrm{N} 7, \mathrm{O} 2-$ $\mathrm{C} 13-\mathrm{C} 11-\mathrm{C} 12, \mathrm{O} 3-\mathrm{C} 14-\mathrm{C} 13-\mathrm{C} 11$ and $\mathrm{O} 4-\mathrm{C} 20-\mathrm{C} 14-$ C13; Fig. 1) were defined as variables in the calculation. The maximum number of simulated annealing moves per run was fixed at 10000000 . Ten runs were performed and led each time to the same solution with a profile factor $\chi^{2}$ close to 17.5. The position and orientation of the molecule, as well as all the torsion angles, are exactly the same for the nine structures obtained. As a result, this structure was used for the Rietveld refinement.

From this structural model, rigid-body Rietveld refinement was performed using $D A S H$. The refinement was performed in three steps: first, the global isotropic displacement parameter, second, the translation and orientation parameters of the molecule, and third, the five torsion angles.

At this step, new previously fixed parameters were refined. The C15-N7-C12, C16-N7-C12, N7-C12-C11, C12$\mathrm{C} 11-\mathrm{C} 13, \mathrm{C} 11-\mathrm{C} 13-\mathrm{C} 14, \mathrm{C} 13-\mathrm{C} 14-\mathrm{C} 20, \mathrm{C} 14-\mathrm{C} 20-$ $\mathrm{O} 4, \mathrm{C} 13-\mathrm{C} 14-\mathrm{O} 3, \mathrm{O} 2-\mathrm{C} 13-\mathrm{C} 14, \mathrm{C} 12-\mathrm{C} 11-\mathrm{O} 1, \mathrm{C} 22-$ $\mathrm{C} 23-\mathrm{C} 26, \mathrm{C} 21-\mathrm{C} 23-\mathrm{C} 26, \mathrm{C} 23-\mathrm{C} 21-\mathrm{C} 25, \mathrm{C} 18-\mathrm{C} 21-$ $\mathrm{C} 25, \mathrm{C} 19-\mathrm{C} 24-\mathrm{O} 5, \mathrm{~N} 10-\mathrm{C} 24-\mathrm{O} 5, \mathrm{~N} 10-\mathrm{C} 27-\mathrm{O} 6$ and $\mathrm{N} 9-\mathrm{C} 27-\mathrm{O} 6$ angles were refined, while the others were fixed, due to the geometry of the molecule (Fig. 1). The C23$\mathrm{C} 26, \mathrm{C} 21-\mathrm{C} 25, \mathrm{~N} 7-\mathrm{C} 12, \mathrm{C} 12-\mathrm{C} 11, \mathrm{C} 11-\mathrm{C} 13, \mathrm{C} 13-\mathrm{C} 14$, $\mathrm{C} 14-\mathrm{C} 20, \mathrm{C} 20-\mathrm{O} 4, \mathrm{C} 13-\mathrm{O} 2, \mathrm{C} 14-\mathrm{O} 3, \mathrm{C} 11-\mathrm{O} 1, \mathrm{C} 24-\mathrm{O} 5$ and $\mathrm{C} 27-\mathrm{O} 6$ bonds were then refined. The other bonds were fixed to keep the isoalloxazine ring of the molecule planar. These refinements led to a decrease in the $\chi^{2}$ value, which dropped to 8.99 .

The position of the four $\mathrm{H}$ atoms belonging to the hydroxy groups $(-\mathrm{OH})$ in riboflavine have been determined using a three-step numerical approach. First, some structurally reasonable possible positions of the four hydroxy $\mathrm{H}$ atoms were generated based on: (i) the positions of the acceptor and donor heavy atoms (oxygen and nitrogen) in the structure determined from X-ray diffraction and (ii) the use of simple geometric criteria to define hydrogen bonds. In this investigation, two molecules are considered to be hydrogen bonded if (i) the nitrogen-oxygen or oxygen-oxygen distance is less than $3.4 \AA$ and (ii) the $\mathrm{N}-\mathrm{H} \cdots \mathrm{O}$ or $\mathrm{O}-\mathrm{H} \cdots \mathrm{O}$ angle is larger than $150^{\circ}$. This criterion is in some way arbitrary but it has been used successfully in many simulations and allows a wide variety of hydrogen bonds, including more deformed and weaker hydrogen bonds, to be taken into account in the statistics (Lerbret et al., 2005; Ottou Abe et al., 2018).

Second, all the possible generated structures were then minimized using a classical force field in order to rapidly exclude the highest energy structures and/or structures with no obvious long-range hydrogen-bonding organization. These

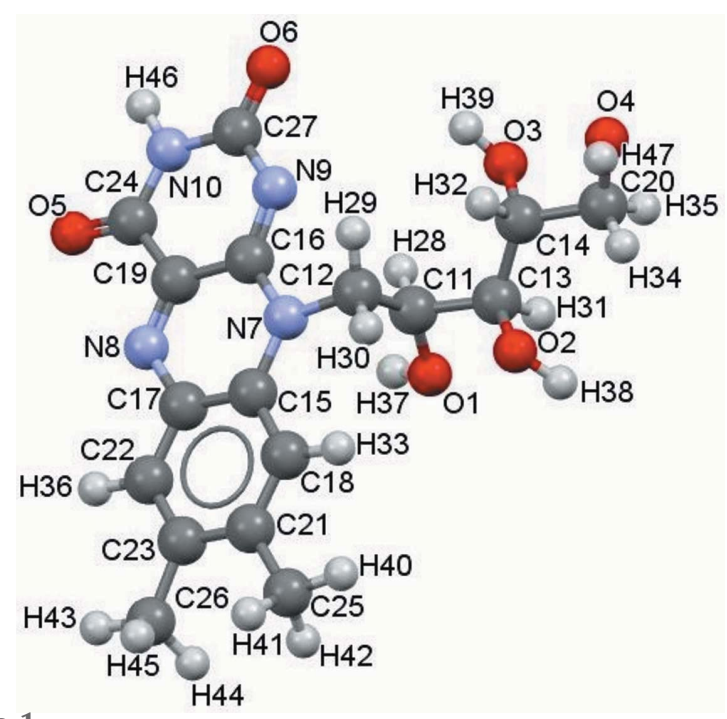

Figure 1

The molecular structure of riboflavin. Colour key: $\mathrm{C}$ atoms are in black. $\mathrm{N}$ atoms blue, $\mathrm{O}$ atoms red and $\mathrm{H}$ atoms white. 
energy minimizations were performed using the $D L \_P O L Y$ package (Smith et al., 2009) and the Generalized Amber Force Field (GAFF) (Wang et al., 2004). Thirdly, the lowest energy structures possible having a clear long-range hydrogenbonding organization were further minimized using periodic density functional theory with fixed-cell dispersion-corrected density functional theory (DFT-D) (Giannozzi et al., 2009, 2017). The Perdew-Burke-Ernzerhof (PBE) functional was used with projector-augmented wave pseudopotentials and the Grimme D3 correction, as implemented in the pw.x executable of the Quantum Espresso program (Giannozzi et al., 2009, 2017).

Atomic coordinates found by DFT calculations were introduced in the programs JANA2020 (Petříček et al., 2014) and MAUD (Materials Analysis Using Diffraction; Lutterotti, 2010) to check the Rietveld refinements and especially to generate the most accurate and complete CIF possible (JANA2020), and to graphically compare the calculated and experimental X-ray diffraction diagrams (MAUD).

At the end of the refinements performed with $J A N A 2020$, the lattice parameters were $a=20.01308(15), b=$ 15.07337 (12), $c=5.31565$ (4) $\AA$ and $V=1603.54$ (2) $\AA^{3}$. The final conventional Rietveld factors were $R=0.083, R_{\mathrm{wp}}=$ 0.1125 and $R_{\exp }=0.0355$. Such factors reflect a good correlation between the observed and simulated X-ray diffraction diagram, as shown in Fig. 2. Crystallographic data, profile and structural parameters are given in Table 1. The final CIF was generated by the JANA2020 software.

\section{Discussion}

To our knowledge, there are only three molecular structures which can be compared to the riboflavin structure obtained here: the computed starting molecule of riboflavin from PubChem, and the trihydrates and complexes formed in association with riboflavin, namely, riboflavin $-5^{\prime}$-bromo- $5^{\prime}$ deoxyadenosine trihydrate (CSD refcode: RIBBAD; Voet \& Rich, 1971) and adenine-riboflavin trihydrate (CSD refcode: ADRBFT10; Fujii et al., 1977).

The geometry of the riboflavin molecule finally obtained in this work was compared with that of the riboflavin molecules used for complex trihydrate association and the computed riboflavin molecule. The different bonds, angles and torsion angles kept free in the refinement are summarized in Table 2.

Differences in the bonds and angles are observed between all the molecules of riboflavin. However, the geometry of the final molecule obtained in the present work seems closer to that of the calculated molecule than to the molecules obtained for the different trihydrates. In particular, the C23-C26 and $\mathrm{C} 21-\mathrm{C} 25$ bonds are longer in the complexes (1.568 and $1.597 \AA$ compared to $1.492 \AA$ for $\mathrm{C} 23-\mathrm{C} 26$, and 1.671 and $1.622 \AA$ compared to $1.493 \AA$ for $\mathrm{C} 21-\mathrm{C} 25)$. Other important differences concern the $\mathrm{C} 11-\mathrm{C} 13, \mathrm{C} 20-\mathrm{O} 4, \mathrm{C} 13-\mathrm{O} 2$ and $\mathrm{C} 14-\mathrm{O} 3$ bonds associated with the $\mathrm{N} 7-\mathrm{C} 12-\mathrm{C} 11, \mathrm{C} 14-$ $\mathrm{C} 20-\mathrm{O} 4$ and $\mathrm{C} 12-\mathrm{C} 11-\mathrm{O} 1$ angles, where the geometries of all the molecules are very different. For example, $\mathrm{C} 20-\mathrm{O} 4$ is $1.41 \AA$ for this work and the computed molecule, and $1.439 \AA$ for RIBBAD compared to $1.667 \AA$ for ADRBFT10. The $\mathrm{C} 14-\mathrm{C} 20-\mathrm{O} 4$ angle ranges between 105.71 and $120.05^{\circ}$ depending on the structure. Noticeable differences are also observed for all the torsion angles between the four molecules, especially for $\mathrm{C} 11-\mathrm{C} 12-\mathrm{N} 7-\mathrm{C} 15$ and $\mathrm{O} 3-\mathrm{C} 14-\mathrm{C} 13-\mathrm{C} 2$. For the $\mathrm{O} 2-\mathrm{C} 13-\mathrm{C} 11-\mathrm{C} 12$ and $\mathrm{O} 4-\mathrm{C} 20-\mathrm{C} 14-\mathrm{C} 23$ torsion angles, similar values were found for the computed riboflavin, the riboflavin from our work and the RIBBAD structure. However, very different values were found $\left(178^{\circ}\right.$ compared to $60^{\circ}$, and $40^{\circ}$ compared to $175^{\circ}$ approximately) for the ADRBFT10 structure. For the torsion angle O1$\mathrm{C} 11-\mathrm{C} 12-\mathrm{N} 7$, the value for the ADRBFT10 structure is also much greater than the values obtained for the three other

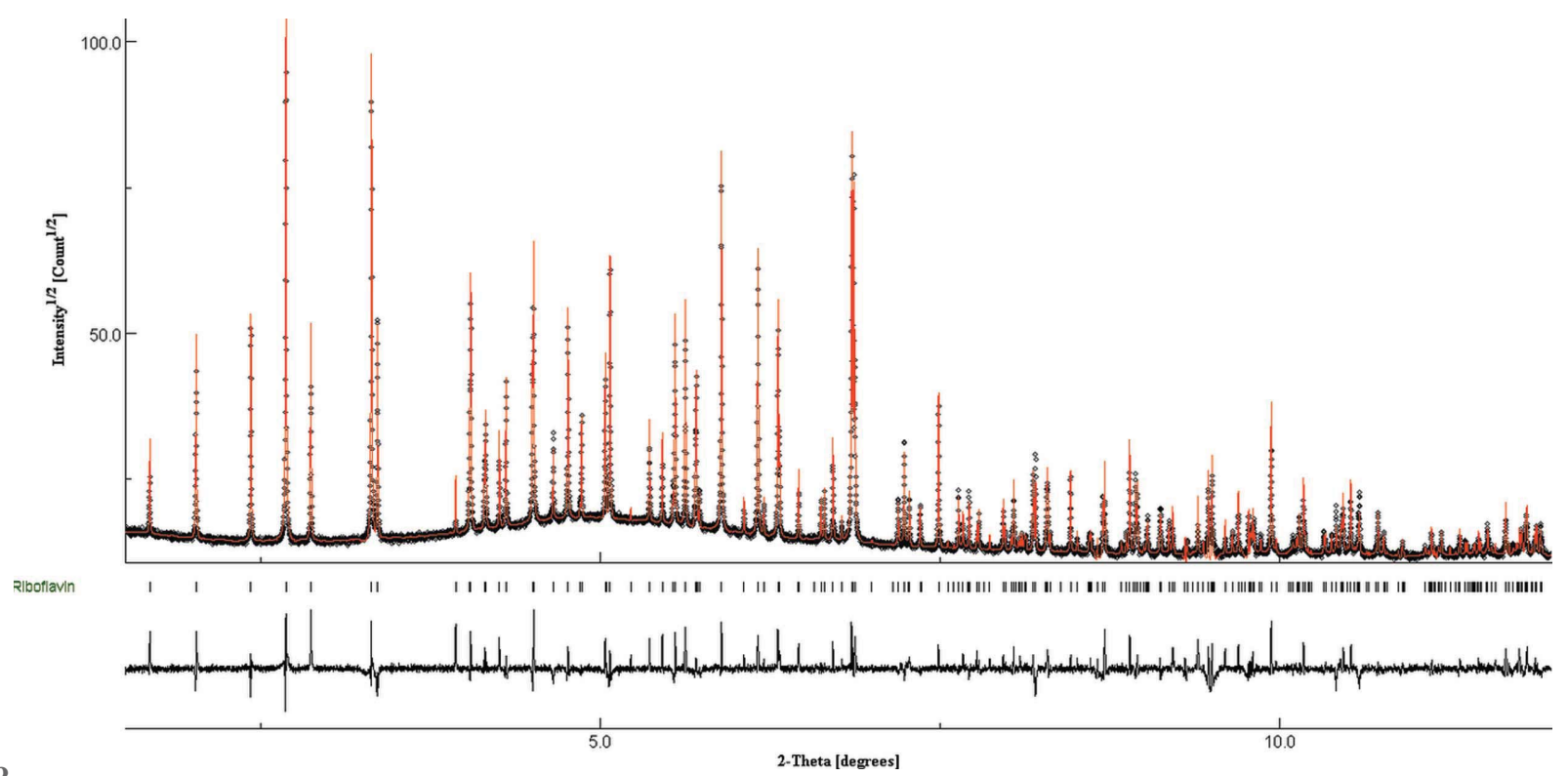

Figure 2

2-Theta [degrees]

The final Rietveld plot of riboflavin at room temperature between 1 and $12^{\circ}$ (MAUD software). The observed intensities are indicated by dots and solid lines represent the best-fit profile (upper trace) and the difference pattern (lower trace). The vertical bars correspond to the positions of the Bragg peaks. 
Table 2

Comparison of the bonds, angles and torsion angles between riboflavin obtained in this work, adenine-riboflavin trihydrate (ADRBFT10) and the complex riboflavin-5'-bromo-5'-deoxyadenosine trihydrate (RIBBAD).

\begin{tabular}{lcccc}
\hline Riboflavin & This work & Computed & RIBBAD & ADRBFT10 \\
\hline Bonds & & & & \\
C23-C26 & 1.492 & 1.4929 & 1.568 & 1.597 \\
C21-C25 & 1.493 & 1.4940 & 1.671 & 1.622 \\
N7-C12 & 1.462 & 1.4621 & 1.439 & 1.546 \\
C12-C11 & 1.532 & 1.5332 & 1.523 & 1.554 \\
C11-C13 & 1.541 & 1.5416 & 1.476 & 1.614 \\
C13-C14 & 1.540 & 1.5405 & 1.636 & 1.569 \\
C14-C20 & 1.527 & 1.5281 & 1.487 & 1.612 \\
C20-O4 & 1.410 & 1.4241 & 1.439 & 1.667 \\
C13-O2 & 1.426 & 1.4270 & 1.316 & 1.478 \\
C14-O3 & 1.428 & 1.4290 & 1.355 & 1.621 \\
C11-O1 & 1.428 & 1.4283 & 1.419 & 1.551 \\
C24-O5 & 1.218 & 1.2189 & 1.168 & 1.203 \\
C27-O6 & 1.232 & 1.2331 & 1.214 & 1.231 \\
& & & & \\
Angles & & & & \\
C15-N7-C12 & 127.03 & 118.14 & 127.11 & 121.40 \\
C16-N7-C12 & 113.33 & 121.71 & 119.40 & 118.02 \\
N7-C12-C11 & 97.55 & 110.02 & 116.53 & 105.85 \\
C12-C11-C13 & 107.65 & 112.64 & 114.89 & 108.25 \\
C11-C13-C14 & 117.62 & 113.03 & 109.62 & 114.36 \\
C13-C14-C20 & 119.05 & 112.36 & 112.22 & 114.15 \\
C14-C20-O4 & 109.94 & 108.78 & 120.05 & 105.71 \\
C13-C14-O3 & 108.19 & 109.07 & 105.53 & 100.50 \\
O2-C13-C14 & 113.71 & 108.65 & 110.84 & 100.50 \\
C12-C11-O1 & 137.07 & 108.56 & 107.15 & 108.71 \\
C22-C23-C26 & 125.71 & 119.24 & 114.12 & 120.97 \\
C21-C23-C26 & 114.69 & 121.18 & 113.89 & 121.95 \\
C23-C21-C25 & 120.91 & 120.91 & 130.30 & 119.46 \\
C18-C21-C25 & 119.00 & 119.01 & 103.91 & 117.55 \\
C19-C24-O5 & 125.06 & 120.61 & 125.12 & 120.79 \\
N10-C24-O5 & 123.07 & 127.52 & 123.51 & 124.93 \\
N10-C27-O6 & 124.57 & 119.22 & 121.15 & 109.51 \\
N9-C27-O6 & 115.83 & 121.17 & 121.14 & 127.18 \\
Torsion angles & & & & \\
C11-C12-N7-C15 & 90.66 & -90 & 88.38 & 99.45 \\
O1-C11-C12-N7 & -49.93 & -58.65 & -54.54 & -74.90 \\
O2-C13-C11-C12 & 61.4 & -58.35 & -53.16 & 178.73 \\
O3-C14-C13-C11 & -55.47 & 178.94 & -49.04 & -73.09 \\
O4-C20-C14-C13 & -161.74 & -178.54 & -172.38 & 40 \\
\hline & & & &
\end{tabular}

structures. Such differences are explained by the mobility of the $\mathrm{N} 7-\mathrm{C} 12-\mathrm{C} 11-\mathrm{C} 13-\mathrm{C} 14-\mathrm{C} 20$ part of the molecules, which can move in function of the molecular environment in the cell. This leads obviously to different hydrogen bonds and crystallographic structure for riboflavin, RIBBAD and ADRBFT10.

The lattice parameters of riboflavin, RIBBAD and ADRBFT10 are given in Table 3. Riboflavin and RIBBAD are orthorhombic with $P 2_{1} 2_{1} 2_{1}$ symmetry for both, while ADRBFT10 is monoclinic with $P 2_{1}$ symmetry. Both trihydrates have small lattice parameters in two directions (close to 7 and

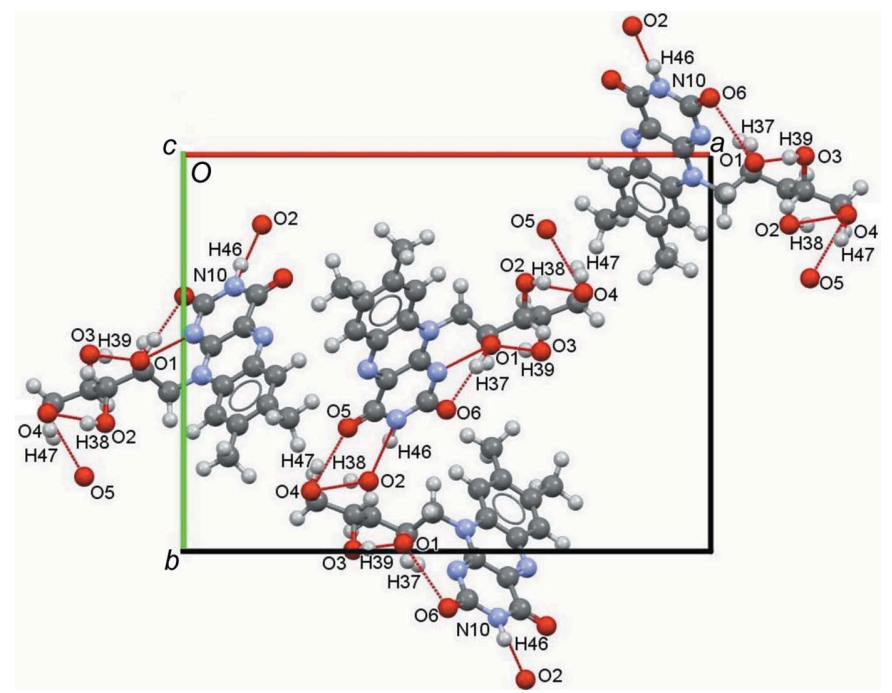

Figure 3

Visualization of the hydrogen-bond network. Generic atom labels without symmetry codes have been used.

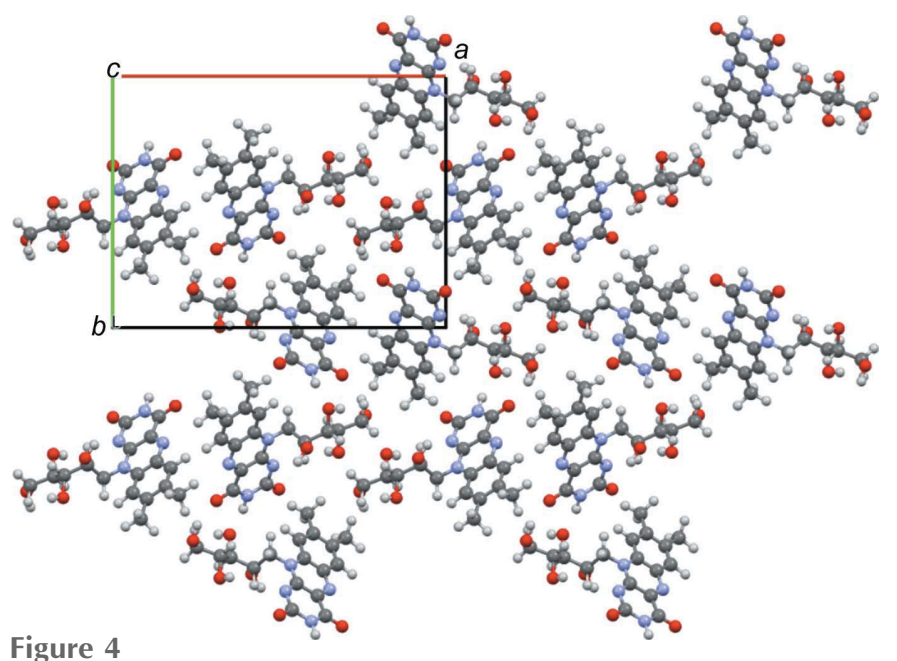

Figure 4

Projection of the unit cell of riboflavin along the [001] direction.

$8 \AA$ for $a$ and $b$ ) and a larger lattice parameter greater than $37 \AA$ for the $c$ direction. In contrast, the crystallographic unit cell obtained here for pure riboflavin has one small parameter (close to $5 \AA$ ) and two large parameters (close to 15 and $20 \AA$ ).

From our calculations, we show that the riboflavin molecules are connected to each other by a network of hydrogen bonds involving $\mathrm{N}-\mathrm{H} \cdots \mathrm{O}\left(\mathrm{N} 10-\mathrm{H} 46 \cdots \mathrm{O} 2^{\text {vi }}\right.$; Table 4$)$ and $\mathrm{O}-\mathrm{H} \cdots \mathrm{O}\left(\mathrm{O} 1-\mathrm{H} 37 \cdots \mathrm{O} 6^{\mathrm{i}}, \mathrm{O} 3-\mathrm{H} 39 \cdots \mathrm{O} 1^{\mathrm{ii}}, \mathrm{O} 2-\mathrm{H} 38 \cdots\right.$ $\mathrm{O} 4^{\mathrm{i}}$ and $\mathrm{O} 4-\mathrm{H} 47 \cdots \mathrm{O} 5^{\mathrm{iii}}$; Table 4 ) bonds (Fig. 3). Molecules are stacked along the $b$ axis, with a mirror inversion between each molecule and along the $a$ axis with a mirror inversion

Table 3

Comparison of the lattice parameters $\left(\AA,^{\circ}\right)$ between riboflavin obtained in this work, adenine-riboflavin trihydrate (ADRBFT10) and the complex riboflavin-5'-bromo-5'-deoxyadenosine trihydrate (RIBBAD).

\begin{tabular}{llllllll}
\hline Structure & $a$ & $b$ & $c$ & $\beta$ & $V\left(\AA^{3}\right)$ & Symmetry & Reference \\
\hline Riboflavin & 20.01308 & 15.07337 & 5.31565 & 90 & 1603.54 & Orthorombic $P 2_{1} 2_{1} 2_{1}$ & This work \\
RIBBAD & 7.773 & 8.628 & 47.934 & 90 & 3214.71 & Orthorombic $P 2_{1} 2_{1} 2_{1}$ & Voet \& Rich (1971) \\
ADRBFT10 & 8.53 & 7.88 & 37.82 & 97.83 & 2518.42 & Monoclinic $P 2_{1}$ & Fujii et al. (1977) \\
\hline
\end{tabular}


Figure 5

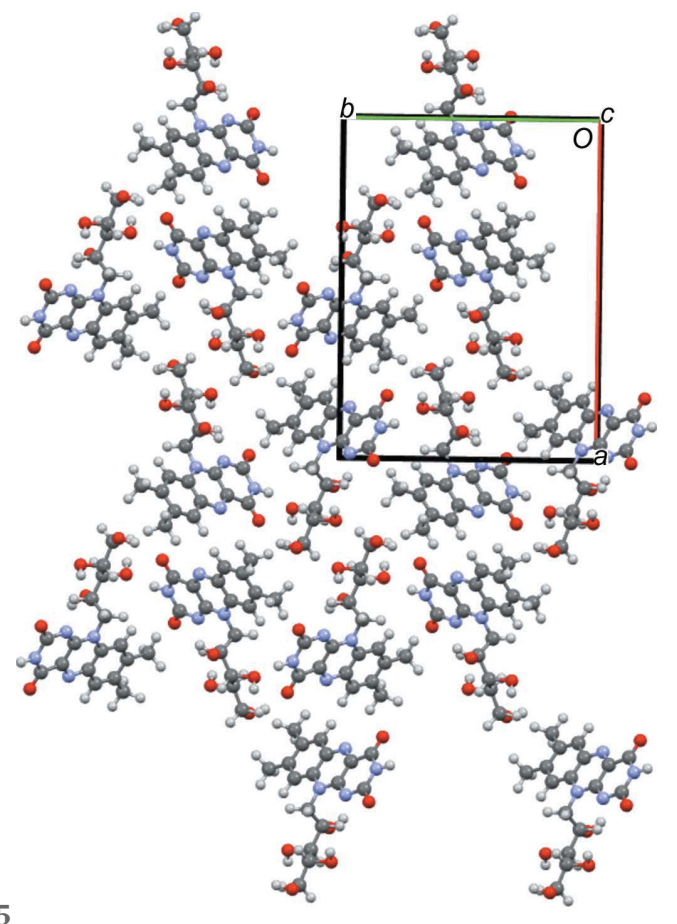

View of the unit cell of riboflavin.

from one molecule to another (see Fig. 4). The molecules form a columnar structure along the $c$ axis (see Fig. 5).

Also, although the RIBBAD structure has the same orthorhombic symmetry and space group as pure riboflavin,
Table 4

Hydrogen-bond geometry $\left(\AA,{ }^{\circ}\right)$.

\begin{tabular}{|c|c|c|c|c|}
\hline$D-\mathrm{H} \cdots A$ & $D-\mathrm{H}$ & $\mathrm{H} \cdots A$ & $D \cdots A$ & $D-\mathrm{H} \cdots A$ \\
\hline $\mathrm{O} 1-\mathrm{H} 37 \cdots \mathrm{O}^{\mathrm{i}}$ & 0.99 & 2.00 & 2.9792 & 171.27 \\
\hline $\mathrm{O} 1-\mathrm{H} 37 \cdots \mathrm{N} 9^{\mathrm{i}}$ & 0.99 & 2.23 & 2.8953 & 123.63 \\
\hline $\mathrm{O} 1-\mathrm{H} 37 \cdots \mathrm{C} 27^{\mathrm{i}}$ & 0.99 & 2.48 & 3.4010 & 155.65 \\
\hline $\mathrm{O} 2-\mathrm{H} 38 \cdots \mathrm{O} 4^{\mathrm{i}}$ & 1.00 & 1.98 & 2.9534 & 165.41 \\
\hline $\mathrm{O} 3-\mathrm{H} 39 \ldots \mathrm{O} 1^{\mathrm{ii}}$ & 1.00 & 1.70 & 2.6718 & 163.30 \\
\hline $\mathrm{O} 4-\mathrm{H} 47 \cdots \mathrm{O} 5^{\mathrm{iii}}$ & 1.00 & 1.95 & 2.8795 & 153.19 \\
\hline $\mathrm{N} 10-\mathrm{H} 46 \cdots \mathrm{O} 2^{\text {iv }}$ & 1.02 & 1.91 & 2.9070 & 166.80 \\
\hline
\end{tabular}

the lattice parameters of the two structures are very different. This is due to the insertion of water and bromo- $5^{\prime}$-deoxyadenosine molecules between the riboflavin molecules in the crystal lattice of RIBBAD (Fig. 6). Indeed, in the RIBBAD crystal structure, the two planar rings are joined by two hydrogen bonds (Voet \& Rich, 1971). The adenine amino group and the imidazole $\mathrm{N}$ atom are involved in hydrogen bonding, and the adenine ring is found to be joined by two hydrogen bonds to the riboflavin isoalloxazine ring. These are bonded to riboflavin isoalloxazine atoms 06 and N10. In addition, the riboflavin and adenosine molecules form an infinite stack of alternating parallel adenine and isoalloxazine rings that is parallel to the $a$ axis (Voet \& Rich, 1971). Riboflavin molecules are also stacked along the $c$ axis, with a mirror projection from one molecule to another and the insertion of bromo-5'-deoxyadenosine molecules between them, leading to a larger $c$-axis value (Fig. 6). This complex structure leads to

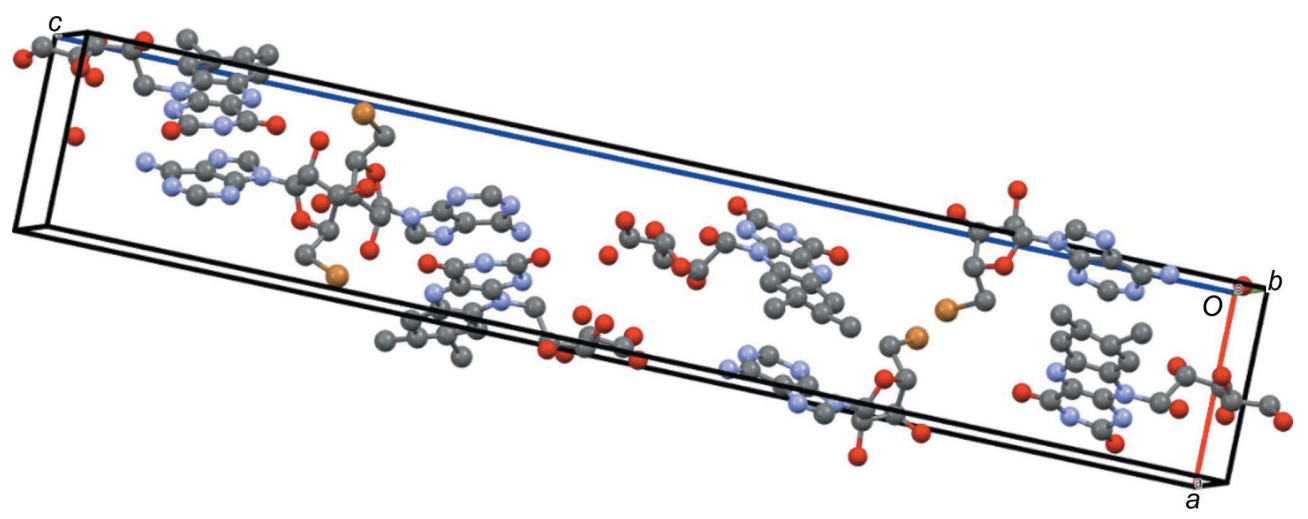

Figure 6

View of the unit cell of the complex riboflavin-5'-bromo-5'-deoxyadenosine trihydrate (RIBBAD; Voet \& Rich, 1971). Br atoms are shown in orange.

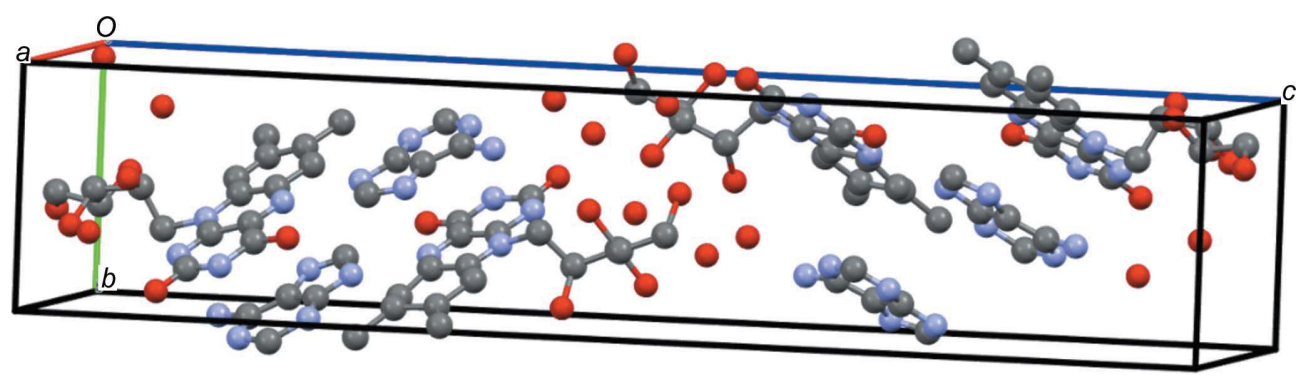

Figure 7

View of the unit cell of adenine-riboflavin trihydrate (ADRBFT10; Fujii et al., 1977). 
a very large $c$ parameter of $47.934 \AA$, compared to $a=$ $20.013 \AA$ for the largest unit-cell parameter in the case of pure riboflavin.

For the ADRBFT10 structure, each riboflavin molecule is associated with a particular adenine molecule via two hydrogen bonds, one involving riboflavin atom $\mathrm{O} 6$ and the other involving riboflavin atom N9 (Fujii et al., 1977). Due to the insertion of the molecules of adenine and water in the structure, the adenine and isoalloxazine rings of riboflavin in each complex molecule interact with each other to form an infinite alternating stacking arrangement (Fig. 7). The molecules are stacked along the $c$ axis, with a mirror projection from one molecule to another. This leads to four riboflavin and four adenine molecules in the unit cell. A monoclinic structure is obtained with a $c$ parameter of $37.82 \AA$, which is much longer than the longest parameter of the pure compound.

The mirror projection of the riboflavin molecules relative to each other appears to be common for the three crystallographic structures containing this molecule. Compared to pure riboflavin, the trihydrates have a more complex unit cell due to either the size or the arrangement of the molecules of the other compound present in the cell with riboflavin.

\section{Acknowledgements}

This project has received funding from the Horizon 2020 research and innovation program of the European Union under a Marie Sktodowska-Curie grant agreement and from the Interreg 2 Seas programme 2014-2020 cofunded by the European Regional Development Fund.

\section{Funding information}

Funding for this research was provided by: European Union (grant No. 847568); Interreg 2 Seas programme 2014-2020 (subsidiary contract No. 2S01-059_IMODE).

\section{References}

Al-Shammary, F. J., Zubair, M. U., Mian, M. S. \& Mian, N. A. A. (1990). Analytical Profiles of Drug Substances, Vol. 19, edited by K. Florey, pp. 429-476. New York: Academic Press.

Blagden, N., de Matas, M., Gavan, P. T. \& York, P. (2007). Adv. Drug Deliv. Rev. 59, 617-630.

Bordet, P., Bytchkov, A., Descamps, M., Dudognon, E., Elkaïm, E., Martinetto, P., Pagnoux, W., Poulain, A. \& Willart, J.-F. (2016). Cryst. Growth Des. 16, 4547-4558.

Boultif, A. \& Louër, D. (2004). J. Appl. Cryst. 37, 724-731.

Chu, K. R., Lee, E., Jeong, S. H. \& Park, E.-S. (2012). Arch. Pharm. Res. 35, 1187-1195.

Dale, J. K. (1952). Crystalline form of riboflavin. US Patent US2603633A.
David, W. I. F., Shankland, K., van de Streek, J., Pidcock, E., Motherwell, W. D. S. \& Cole, J. C. (2006). J. Appl. Cryst. 39, 910915.

Dejoie, C., Coduri, M., Petitdemange, S., Giacobbe, C., Covacci, E., Grimaldi, O., Autran, P.-O., Mogodi, M. W., Šišak Jung, D. \& Fitch, A. N. (2018). J. Appl. Cryst. 51, 1721-1733.

Farias, S. S. de, Siqueira, S. M. C., Cunha, A. P., de Souza, C. A. G., dos Santos Fontenelle, R. O., de Araújo, T. G., de Amorim, A. F. V., de Menezes, J. E. S. A., de Morais, S. M. \& Ricardo, N. M. P. S. (2018). Ind. Crops Prod. 118, 271-281.

Ferreira, L. T., Alarcon, R. T., Perpétuo, G. L. \& Bannach, G. (2019). J. Therm. Anal. Calorim. 136, 581-588.

Fujii, S., Kawasaki, K., Sato, A., Fujiwara, T. \& Tomita, K.-I. (1977). Arch. Biochem. Biophys. 181, 363-370.

Furia, T. E. (1972). Editor. CRC Handbook of Food Additives. Cleveland: CRC Press.

Giannozzi, P., et al. (2009). J. Phys. Condes. Matter, 21, 395502.

Giannozzi, P., et al. (2017). J. Phys. Condes. Matter, 29, 465901.

Groom, C. R., Bruno, I. J., Lightfoot, M. P. \& Ward, S. C. (2016). Acta Cryst. B72, 171-179.

Lerbret, A., Bordat, P., Affouard, F., Descamps, M. \& Migliardo, F. (2005). J. Phys. Chem. B, 109, 11046-11057.

Lutterotti, L. (2010). Nucl. Instrum. Methods Phys. Res. B, 268, 334340.

Macrae, C. F., Sovago, I., Cottrell, S. J., Galek, P. T. A., McCabe, P., Pidcock, E., Platings, M., Shields, G. P., Stevens, J. S., Towler, M. \& Wood, P. A. (2020). J. Appl. Cryst. 53, 226-235.

Mahieu, A., Willart, J.-F., Dudognon, E., Danède, F. \& Descamps, M. (2013). Mol. Pharm. 10, 560-566.

Markvardsen, A. J., Shankland, K., David, W. I. F., Johnston, J. C., Ibberson, R. M., Tucker, M., Nowell, H. \& Griffin, T. (2008). J. Appl. Cryst. 41, 1177-1181.

Martinetto, P., Bordet, P., Descamps, M., Dudognon, E., Pagnoux, W. \& Willart, J.-F. (2017). Cryst. Growth Des. 17, 6111-6122.

Means, J. A., Grenfell, T. C. \& Hedger, F. H. (1943). J. Am. Pharm. Assoc. (Sci. ed.), 32, 51-53.

Ottou Abe, M. T., Viciosa, M. T., Correia, N. T. \& Affouard, F. (2018). Phys. Chem. Chem. Phys. 20, 29528-29538.

Pawley, G. S. (1981). J. Appl. Cryst. 14, 357-361.

Petřriček, V., Dušek, M. \& Palatinus, L. (2014). Z. Kristallogr. 229, 345-352.

Saifee, M., Inamda, N., Dhamecha, D. \& Rathi, A. (2010). Int. J. Health Res. 3, 57-70.

Smith, G. S. \& Snyder, R. L. (1979). J. Appl. Cryst. 12, 60-65.

Smith, W., Forester, T. R. \& Todorov, I. T. T. (2009). The DL_POLY_2 User Manual. STFC Daresbury Laboratory, Warrington, UK. http://users.clas.ufl.edu/hping/teaching/Fall2012/ USRMAN2.20.pdf.

Voet, D. \& Rich, A. (1971). Proc. Natl Acad. Sci. USA, 68, 1151-1156. Wang, J., Wolf, R. M., Caldwell, J. W., Kollman, P. A. \& Case, D. A. (2004). J. Comput. Chem. 25, 1157-1174.

Willart, J. F. \& Descamps, M. (2008). Mol. Pharm. 5, 905-920.

Willart, J.-F., Lefebvre, J., Danède, F., Comini, S., Looten, P. \& Descamps, M. (2005). Solid State Commun. 135, 519-524.

Wolff, P. M. de (1968). J. Appl. Cryst. 1, 108-113.

Zimper, U., Aaltonen, J., Krauel-Goellner, K., Gordon, K. C., Strachan, C. J. \& Rades, T. (2010a). Pharmaceutics, 2, 419-431.

Zimper, U., Aaltonen, J., McGoverin, C. M., Gordon, K. C., KrauelGoellner, K. \& Rades, T. (2010b). Pharmaceutics, 2, 30-49. 


\section{supporting information}

Acta Cryst. (2021). C77, 800-806 [https://doi.org/10.1107/S2053229621012171]

Structure determination of riboflavin by synchrotron high-resolution powder Xray diffraction

Mathieu Guerain, Frédéric Affouard, Charline Henaff, Catherine Dejoie, Florence Danède, Juergen Siepman, Florence Siepman and Jean-François Willart

Computing details

$\backslash 7,8$-Dimethyl-10-[(2R,3R,4S)-2,3,4,5-tetrahydroxypentyl] $]$ benzo[g]pteridine-2,4(3H,10H)-dione

Crystal data

$\mathrm{C}_{68} \mathrm{H}_{80} \mathrm{~N}_{16} \mathrm{O}_{24}$

$M_{r}=1505.5$

$V=1603.54(2) \AA^{3}$

Orthorhombic, $P 2_{1} 22_{1}$

$Z=1$

Hall symbol: P 2xab;2ybc;2zac

$F(000)=792$

$a=20.01308(15) \AA$

$D_{\mathrm{x}}=1.559 \mathrm{Mg} \mathrm{m}^{-3}$

$b=15.07337(12) \AA$

$c=5.31565(4) \AA$

Synchrotron radiation

$T=293 \mathrm{~K}$

orange

Data collection

Synchrotron

$2 \theta_{\min }=1.5^{\circ}, 2 \theta_{\max }=12^{\circ}, 2 \theta_{\text {step }}=0.001^{\circ}$

diffractometer

Refinement

$R_{\mathrm{p}}=0.084$

$R_{\text {wp }}=0.113$

$R_{\text {exp }}=0.036$

$R(F)=0.125$

10501 data points

Profile function: Pseudo-Voigt

18 parameters

0 restraints

0 constraints

$\mathrm{H}$-atom parameters constrained

Weighting scheme based on measured s.u.'s

$(\Delta / \sigma)_{\max }=0.042$

Background function: 8 Legendre polynoms

Preferred orientation correction: none

Fractional atomic coordinates and isotropic or equivalent isotropic displacement parameters $\left(\AA^{2}\right)$

\begin{tabular}{lllll}
\hline & $x$ & $y$ & $z$ & $U_{\mathrm{iso}} * / U_{\mathrm{eq}}$ \\
\hline O1 & 0.08278 & 0.02019 & 0.34375 & $0.0422^{*}$ \\
O2 & 0.14877 & 0.17673 & 0.1441 & $0.0422^{*}$ \\
O3 & 0.1782 & 0.00367 & -0.30786 & $0.0422^{*}$ \\
O4 & 0.2585 & 0.15191 & -0.4911 & $0.0422^{*}$ \\
O5 & -0.18857 & -0.1883 & -0.14607 & $0.0422^{*}$ \\
O6 & -0.00119 & -0.14281 & -0.63307 & $0.0422^{*}$ \\
N7 & -0.0342 & 0.05621 & 0.01071 & $0.0422^{*}$ \\
N8 & -0.15114 & -0.04125 & 0.12809 & $0.0422 *$
\end{tabular}




\begin{tabular}{|c|c|c|c|c|}
\hline N9 & -0.01887 & -0.04842 & -0.32105 & $0.0422 *$ \\
\hline N10 & -0.09618 & -0.16737 & -0.39024 & $0.0422^{*}$ \\
\hline C11 & 0.07628 & 0.04441 & 0.08517 & $0.0422 *$ \\
\hline $\mathrm{C} 12$ & 0.02745 & 0.09824 & -0.07628 & $0.0422^{*}$ \\
\hline $\mathrm{C} 13$ & 0.1459 & 0.08712 & 0.0583 & $0.0422 *$ \\
\hline C14 & 0.17662 & 0.09153 & -0.20707 & $0.0422 *$ \\
\hline $\mathrm{C} 15$ & -0.07468 & 0.08311 & 0.21446 & $0.0422 *$ \\
\hline $\mathrm{C} 16$ & -0.05221 & -0.01772 & -0.13003 & $0.0422 *$ \\
\hline $\mathrm{C} 17$ & -0.13261 & 0.03352 & 0.26915 & $0.0422 *$ \\
\hline $\mathrm{C} 18$ & -0.06043 & 0.15703 & 0.36703 & $0.0422 *$ \\
\hline C19 & -0.115 & -0.06582 & -0.05558 & $0.0422 *$ \\
\hline $\mathrm{C} 20$ & 0.24751 & 0.12748 & -0.23832 & $0.0422 *$ \\
\hline $\mathrm{C} 21$ & -0.10212 & 0.18092 & 0.56672 & $0.0422 *$ \\
\hline $\mathrm{C} 22$ & -0.17413 & 0.05808 & 0.47014 & $0.0422 *$ \\
\hline $\mathrm{C} 23$ & -0.15899 & 0.13144 & 0.61835 & $0.0422 *$ \\
\hline $\mathrm{C} 24$ & -0.13836 & -0.14599 & -0.19538 & $0.0422 *$ \\
\hline $\mathrm{C} 25$ & -0.08446 & 0.26007 & 0.72221 & $0.0422 *$ \\
\hline $\mathrm{C} 26$ & -0.19914 & 0.16405 & 0.83614 & $0.0422 *$ \\
\hline $\mathrm{C} 27$ & -0.03807 & -0.12201 & -0.4569 & $0.0422 *$ \\
\hline $\mathrm{H} 28$ & 0.0753 & -0.02438 & 0.01942 & $0.0844^{*}$ \\
\hline H30 & 0.0256 & 0.16899 & -0.02712 & $0.0844 *$ \\
\hline $\mathrm{H} 29$ & 0.03236 & 0.09849 & -0.28129 & $0.0844 *$ \\
\hline H31 & 0.18212 & 0.05117 & 0.17488 & $0.0844 *$ \\
\hline H32 & 0.14479 & 0.13134 & -0.33112 & $0.0844 *$ \\
\hline H33 & -0.01711 & 0.19856 & 0.3321 & $0.0844^{*}$ \\
\hline H34 & 0.25377 & 0.19418 & -0.16174 & $0.0844^{*}$ \\
\hline H35 & 0.28442 & 0.08334 & -0.15236 & $0.0844^{*}$ \\
\hline H36 & -0.21862 & 0.01891 & 0.5092 & $0.0844 *$ \\
\hline H37 & 0.05569 & -0.03376 & 0.37017 & $0.0844 *$ \\
\hline H38 & 0.1827 & 0.17751 & 0.28129 & $0.0844 *$ \\
\hline H39 & 0.14921 & 0.00731 & -0.46058 & $0.0844 *$ \\
\hline $\mathrm{H} 40$ & -0.03823 & 0.29162 & 0.65755 & $0.0844 *$ \\
\hline H41 & -0.12394 & 0.31018 & 0.7116 & $0.0844 *$ \\
\hline $\mathrm{H} 42$ & -0.0767 & 0.241 & 0.91873 & $0.0844^{*}$ \\
\hline $\mathrm{H} 43$ & -0.24335 & 0.12276 & 0.86886 & $0.0844 *$ \\
\hline H44 & -0.16945 & 0.16268 & 1.00905 & $0.0844^{*}$ \\
\hline $\mathrm{H} 45$ & -0.21685 & 0.23171 & 0.80197 & $0.0844 *$ \\
\hline H46 & -0.10838 & -0.22121 & -0.49571 & $0.0844 *$ \\
\hline H47 & 0.24692 & 0.21388 & -0.49935 & $0.0844 *$ \\
\hline
\end{tabular}

Geometric parameters $\left(A,{ }^{o}\right)$

\begin{tabular}{llll}
\hline $\mathrm{O} 1-\mathrm{C} 11$ & $1.4281(1)$ & $\mathrm{C} 13-\mathrm{C} 14$ & $1.5402(1)$ \\
$\mathrm{O} 1-\mathrm{H} 37$ & $0.9874(1)$ & $\mathrm{C} 13-\mathrm{H} 31$ & 1.0969 \\
$\mathrm{O} 2-\mathrm{C} 13$ & $1.4268(1)$ & $\mathrm{C} 14-\mathrm{C} 20$ & $1.5278(1)$ \\
$\mathrm{O} 2-\mathrm{H} 38$ & 0.9965 & $\mathrm{C} 14-\mathrm{H} 32$ & 1.0958 \\
$\mathrm{O} 3-\mathrm{C} 14$ & $1.4290(1)$ & $\mathrm{C} 15-\mathrm{C} 17$ & $1.4097(1)$ \\
$\mathrm{O} 3-\mathrm{H} 39$ & $0.9993(1)$ & $\mathrm{C} 15-\mathrm{C} 18$ & $1.4073(1)$
\end{tabular}




\begin{tabular}{|c|c|c|c|}
\hline $\mathrm{O} 4-\mathrm{C} 20$ & $1.4105(1)$ & $\mathrm{C} 16-\mathrm{C} 19$ & $1.5038(1)$ \\
\hline $\mathrm{O} 4-\mathrm{H} 47$ & $0.9600(1)$ & $\mathrm{C} 17-\mathrm{C} 22$ & $1.4032(1)$ \\
\hline $\mathrm{O} 5-\mathrm{C} 24$ & $1.2187(1)$ & $\mathrm{C} 18-\mathrm{C} 21$ & $1.3973(1)$ \\
\hline $\mathrm{O} 6-\mathrm{C} 27$ & $1.2329(1)$ & C18-H33 & $1.0854(1)$ \\
\hline $\mathrm{N} 7-\mathrm{C} 12$ & $1.4620(1)$ & $\mathrm{C} 19-\mathrm{C} 24$ & $1.4937(1)$ \\
\hline $\mathrm{N} 7-\mathrm{C} 15$ & $1.4120(1)$ & $\mathrm{C} 20-\mathrm{H} 34$ & $1.0919(1)$ \\
\hline $\mathrm{N} 7-\mathrm{C} 16$ & $1.3898(1)$ & $\mathrm{C} 20-\mathrm{H} 35$ & 1.0941 \\
\hline $\mathrm{N} 8-\mathrm{C} 17$ & $1.4036(1)$ & $\mathrm{C} 21-\mathrm{C} 23$ & $1.3882(1)$ \\
\hline $\mathrm{N} 8-\mathrm{C} 19$ & $1.2702(1)$ & $\mathrm{C} 21-\mathrm{C} 25$ & $1.4938(1)$ \\
\hline N9- $\mathrm{C} 16$ & $1.3001(1)$ & $\mathrm{C} 22-\mathrm{C} 23$ & $1.3911(1)$ \\
\hline N9- $\mathrm{C} 27$ & $1.3782(1)$ & $\mathrm{C} 22-\mathrm{H} 36$ & $1.0883(1)$ \\
\hline $\mathrm{N} 10-\mathrm{C} 24$ & $1.3745(1)$ & $\mathrm{C} 23-\mathrm{C} 26$ & $1.4925(1)$ \\
\hline $\mathrm{N} 10-\mathrm{C} 27$ & $1.3948(1)$ & $\mathrm{C} 25-\mathrm{H} 40$ & $1.0956(1)$ \\
\hline $\mathrm{N} 10-\mathrm{H} 46$ & $1.0161(1)$ & $\mathrm{C} 25-\mathrm{H} 41$ & $1.0945(1)$ \\
\hline $\mathrm{C} 11-\mathrm{C} 12$ & $1.5329(1)$ & $\mathrm{C} 25-\mathrm{H} 42$ & $1.0945(1)$ \\
\hline $\mathrm{C} 11-\mathrm{C} 13$ & $1.5415(1)$ & $\mathrm{C} 26-\mathrm{H} 43$ & $1.0957(1)$ \\
\hline $\mathrm{C} 11-\mathrm{H} 28$ & $1.0944(1)$ & $\mathrm{C} 26-\mathrm{H} 44$ & $1.0947(1)$ \\
\hline $\mathrm{C} 12-\mathrm{H} 30$ & $1.0986(1)$ & $\mathrm{C} 26-\mathrm{H} 45$ & $1.0949(1)$ \\
\hline $\mathrm{C} 12-\mathrm{H} 29$ & $1.0942(1)$ & & \\
\hline $\mathrm{C} 11-\mathrm{O} 1-\mathrm{H} 37$ & $107.3025(1)$ & $\mathrm{N} 8-\mathrm{C} 17-\mathrm{C} 15$ & $122.2009(3)$ \\
\hline $\mathrm{C} 13-\mathrm{O} 2-\mathrm{H} 38$ & $105.8145(2)$ & $\mathrm{N} 8-\mathrm{C} 17-\mathrm{C} 22$ & $117.5258(3)$ \\
\hline $\mathrm{C} 14-\mathrm{O} 3-\mathrm{H} 39$ & $103.9365(2)$ & $\mathrm{C} 15-\mathrm{C} 17-\mathrm{C} 22$ & $120.2733(3)$ \\
\hline $\mathrm{C} 20-\mathrm{O} 4-\mathrm{H} 47$ & $102.1133(2)$ & $\mathrm{C} 15-\mathrm{C} 18-\mathrm{C} 21$ & $121.3861(3)$ \\
\hline $\mathrm{C} 12-\mathrm{N} 7-\mathrm{C} 15$ & $127.0389(3)$ & $\mathrm{C} 15-\mathrm{C} 18-\mathrm{H} 33$ & $121.3277(3)$ \\
\hline $\mathrm{C} 12-\mathrm{N} 7-\mathrm{C} 16$ & $113.3331(3)$ & $\mathrm{C} 21-\mathrm{C} 18-\mathrm{H} 33$ & $117.2758(3)$ \\
\hline $\mathrm{C} 15-\mathrm{N} 7-\mathrm{C} 16$ & $119.6280(3)$ & $\mathrm{N} 8-\mathrm{C} 19-\mathrm{C} 16$ & $122.5147(3)$ \\
\hline $\mathrm{C} 17-\mathrm{N} 8-\mathrm{C} 19$ & $119.6233(3)$ & $\mathrm{N} 8-\mathrm{C} 19-\mathrm{C} 24$ & $116.1079(3)$ \\
\hline $\mathrm{C} 16-\mathrm{N} 9-\mathrm{C} 27$ & $123.5440(3)$ & $\mathrm{C} 16-\mathrm{C} 19-\mathrm{C} 24$ & $121.3774(3)$ \\
\hline $\mathrm{C} 24-\mathrm{N} 10-\mathrm{C} 27$ & $126.0548(3)$ & $\mathrm{O} 4-\mathrm{C} 20-\mathrm{C} 14$ & 109.94 \\
\hline $\mathrm{C} 24-\mathrm{N} 10-\mathrm{H} 46$ & $117.0943(3)$ & $\mathrm{O} 4-\mathrm{C} 20-\mathrm{H} 34$ & $95.5592(3)$ \\
\hline $\mathrm{C} 27-\mathrm{N} 10-\mathrm{H} 46$ & $116.8510(3)$ & $\mathrm{O} 4-\mathrm{C} 20-\mathrm{H} 35$ & $116.8289(2)$ \\
\hline $\mathrm{O} 1-\mathrm{C} 11-\mathrm{C} 12$ & $137.0727(1)$ & $\mathrm{C} 14-\mathrm{C} 20-\mathrm{H} 34$ & $113.1172(2)$ \\
\hline $\mathrm{O} 1-\mathrm{C} 11-\mathrm{C} 13$ & $96.5236(1)$ & $\mathrm{C} 14-\mathrm{C} 20-\mathrm{H} 35$ & $111.4603(5)$ \\
\hline $\mathrm{O} 1-\mathrm{C} 11-\mathrm{H} 28$ & $93.8303(3)$ & $\mathrm{H} 34-\mathrm{C} 20-\mathrm{H} 35$ & $109.0728(4)$ \\
\hline $\mathrm{C} 12-\mathrm{C} 11-\mathrm{C} 13$ & $107.6548(4)$ & $\mathrm{C} 18-\mathrm{C} 21-\mathrm{C} 23$ & $120.0851(3)$ \\
\hline $\mathrm{C} 12-\mathrm{C} 11-\mathrm{H} 28$ & $108.1367(4)$ & $\mathrm{C} 18-\mathrm{C} 21-\mathrm{C} 25$ & $119.0038(3)$ \\
\hline $\mathrm{C} 13-\mathrm{C} 11-\mathrm{H} 28$ & $112.4765(2)$ & $\mathrm{C} 23-\mathrm{C} 21-\mathrm{C} 25$ & $120.9111(3)$ \\
\hline $\mathrm{N} 7-\mathrm{C} 12-\mathrm{C} 11$ & $97.5593(5)$ & $\mathrm{C} 17-\mathrm{C} 22-\mathrm{C} 23$ & $120.7923(3)$ \\
\hline $\mathrm{N} 7-\mathrm{C} 12-\mathrm{H} 30$ & $108.4797(3)$ & $\mathrm{C} 17-\mathrm{C} 22-\mathrm{H} 36$ & $119.1170(3)$ \\
\hline $\mathrm{N} 7-\mathrm{C} 12-\mathrm{H} 29$ & $113.0967(1)$ & $\mathrm{C} 23-\mathrm{C} 22-\mathrm{H} 36$ & $120.0907(3)$ \\
\hline $\mathrm{C} 11-\mathrm{C} 12-\mathrm{H} 30$ & 113.7113 (3) & $\mathrm{C} 21-\mathrm{C} 23-\mathrm{C} 22$ & $119.5835(3)$ \\
\hline $\mathrm{C} 11-\mathrm{C} 12-\mathrm{H} 29$ & $120.1427(3)$ & $\mathrm{C} 21-\mathrm{C} 23-\mathrm{C} 26$ & $114.6973(3)$ \\
\hline $\mathrm{H} 30-\mathrm{C} 12-\mathrm{H} 29$ & $103.6849(1)$ & $\mathrm{C} 22-\mathrm{C} 23-\mathrm{C} 26$ & 125.7193 \\
\hline $\mathrm{O} 2-\mathrm{C} 13-\mathrm{C} 11$ & $113.7119(2)$ & $\mathrm{O} 5-\mathrm{C} 24-\mathrm{N} 10$ & $123.0772(3)$ \\
\hline $\mathrm{O} 2-\mathrm{C} 13-\mathrm{C} 14$ & $103.6406(2)$ & $\mathrm{O} 5-\mathrm{C} 24-\mathrm{C} 19$ & $125.0607(3)$ \\
\hline $\mathrm{O} 2-\mathrm{C} 13-\mathrm{H} 31$ & $105.0993(4)$ & $\mathrm{N} 10-\mathrm{C} 24-\mathrm{C} 19$ & $111.8621(3)$ \\
\hline $\mathrm{C} 11-\mathrm{C} 13-\mathrm{C} 14$ & $117.6252(2)$ & $\mathrm{C} 21-\mathrm{C} 25-\mathrm{H} 40$ & $111.8947(3)$ \\
\hline
\end{tabular}



$\mathrm{C} 11-\mathrm{C} 13-\mathrm{H} 31$
$\mathrm{C} 14-\mathrm{C} 13-\mathrm{H} 31$
$\mathrm{O} 3-\mathrm{C} 14-\mathrm{C} 13$
$\mathrm{O} 3-\mathrm{C} 14-\mathrm{C} 20$
$\mathrm{O} 3-\mathrm{C} 14-\mathrm{H} 32$
C13-C14-C20
C13-C14-H32
$\mathrm{C} 20-\mathrm{C} 14-\mathrm{H} 32$
$\mathrm{N} 7-\mathrm{C} 15-\mathrm{C} 17$
$\mathrm{N} 7-\mathrm{C} 15-\mathrm{C} 18$
$\mathrm{C} 17-\mathrm{C} 15-\mathrm{C} 18$
N7- $16-\mathrm{N} 9$
$\mathrm{N} 7-\mathrm{C} 16-\mathrm{C} 19$
N9-C16-C19
109.7952 (4)
$105.9598(4)$
$108.1930(2)$
$105.5103(2)$
107.1440 (4)
119.0501 (1)
$110.0430(4)$
106.2713 (4)
$118.5391(3)$
$123.5812(3)$
117.8797 (3)
$124.9396(3)$
$117.4939(3)$
117.5665 (3)
$\mathrm{C} 21-\mathrm{C} 25-\mathrm{H} 41$
$\mathrm{C} 21-\mathrm{C} 25-\mathrm{H} 42$
$\mathrm{H} 40-\mathrm{C} 25-\mathrm{H} 41$
$\mathrm{H} 40-\mathrm{C} 25-\mathrm{H} 42$
$\mathrm{H} 41-\mathrm{C} 25-\mathrm{H} 42$
$\mathrm{C} 23-\mathrm{C} 26-\mathrm{H} 43$
$\mathrm{C} 23-\mathrm{C} 26-\mathrm{H} 44$
$\mathrm{C} 23-\mathrm{C} 26-\mathrm{H} 45$
$\mathrm{H} 43-\mathrm{C} 26-\mathrm{H} 44$
$\mathrm{H} 43-\mathrm{C} 26-\mathrm{H} 45$
$\mathrm{H} 44-\mathrm{C} 26-\mathrm{H} 45$
$\mathrm{O} 6-\mathrm{C} 27-\mathrm{N} 9$
O6- $227-\mathrm{N} 10$
N9-C27-N10

110.6007 (4)

$110.6036(4)$

$107.0916(5)$

107.0733 (2)

109.4413 (1)

$111.7659(3)$

$110.6617(5)$

$110.6332(3)$

$107.1175(3)$

107.1007 (5)

109.4257 (1)

115.8322 (3)

$124.5726(3)$

119.5952 (3)

Hydrogen-bond geometry $\left(\AA,{ }^{\circ}\right)$

\begin{tabular}{lllll}
\hline$D-\mathrm{H} \cdots A$ & $D-\mathrm{H}$ & $\mathrm{H} \cdots A$ & $D \cdots A$ & $D-\mathrm{H} \cdots A$ \\
\hline $\mathrm{C} 20-\mathrm{H} 34 \cdots \mathrm{O} 5^{\mathrm{i}}$ & 1.09 & 2.43 & 3.0789 & 116.98 \\
$\mathrm{C} 20-\mathrm{H} 35 \cdots \mathrm{O} 3^{\mathrm{ii}}$ & 1.09 & 2.37 & 3.3696 & 150.58 \\
$\mathrm{O} 1-\mathrm{H} 37 \cdots 6^{\mathrm{iii}}$ & 0.99 & 2.00 & 2.9792 & 171.27 \\
$\mathrm{O} 1-\mathrm{H} 37 \cdots \mathrm{N} 9^{\mathrm{iii}}$ & 0.99 & 2.23 & 2.8953 & 123.63 \\
$\mathrm{O} 1-\mathrm{H} 37 \cdots \mathrm{C} 27^{\mathrm{iii}}$ & 0.99 & 2.48 & 3.4010 & 155.65 \\
$\mathrm{O} 2-\mathrm{H} 38 \cdots \mathrm{O} 4^{\mathrm{iii}}$ & 1.00 & 1.98 & 2.9534 & 165.41 \\
$\mathrm{O} 3-\mathrm{H} 39 \cdots{ }^{\mathrm{ii}}$ & 1.00 & 1.70 & 2.6718 & 163.30 \\
$\mathrm{O} 4-\mathrm{H} 47 \cdots \mathrm{O} 5^{\mathrm{i}}$ & 1.00 & 1.95 & 2.8795 & 153.19 \\
$\mathrm{C} 26-\mathrm{H} 44 \cdots \mathrm{C} 15^{\mathrm{iii}}$ & 1.09 & 2.50 & 3.4259 & 142.09 \\
$\mathrm{C} 26-\mathrm{H} 44 \cdots \mathrm{C} 17^{\mathrm{iii}}$ & 1.09 & 2.50 & 3.3079 & 129.74 \\
$\mathrm{C} 26-\mathrm{H} 45 \cdots \mathrm{O} 4^{\mathrm{v}}$ & 1.09 & 2.46 & 3.4320 & 147.21 \\
$\mathrm{~N} 10-\mathrm{H} 46 \cdots \mathrm{O} 2^{\mathrm{vi}}$ & 1.02 & 1.91 & 2.9070 & 166.80 \\
\hline
\end{tabular}

Symmetry codes: (i) $-x, y+1 / 2,-z-1 / 2$; (ii) $-x+1 / 2,-y, z+1 / 2$; (iii) $x, y, z+1$; (iv) $x, y, z-1$; (v) $x-1 / 2,-y+1 / 2,-z$; (vi) $-x, y-1 / 2,-z-1 / 2$. 